\title{
Presidents, Prime Ministers and Policy Rhetoric: The 'Credibility Gaps' of Woodrow Wilson and Kevin Rudd in the League of Nations and Climate Change Debates
}

\author{
By Wesley Widmaier and Dennis C. Grube
}

U.S. President Woodrow Wilson and Australian Prime Minister Kevin Rudd were separated by institutional contexts, relative power positions, and decades in time. However, each confronted a similar dilemma - of reconciling rhetorical idealism with policy practicalities. Building on insights from studies of the U.S. rhetorical presidency, we offer a framework highlighting the tensions between 'outside' moral appeals which raise expectations and the 'inside' technocratic rhetoric of policy administration. We argue that norms encouraging moral appeals have come to transcend institutional differences between 'presidential' and 'prime ministerial' systems. Despite the different contexts of the Wilson-era League of Nations debate and the Rudd-era carbon tax-Kyoto controversies, we argue that pressures to 'speak in two voices' engendered credibility gaps that undermined each leader's congressional and parliamentary support. In concluding, we suggest that this analysis supports a more nuanced appreciation of the rhetorical imperatives that can impede policy efficiency - and the need to limit tendencies to either populist or intellectual partisanship.

\section{Introduction and Overview}

How do different types of rhetoric enable or impede change? To what extent do efforts by leaders to construct moral challenges engender 'revolutions of rising expectations' that are undercut by more technocratic or transactional rhetoric? We consider here two leaders whose policy ambitions were frustrated by 'credibility gaps' between their 'outside' popular rhetoric and 'inside' intellectual and policy deliberations: While U.S. President Woodrow Wilson and Australian Prime Minister Kevin Rudd were separated by institutional contexts of presidential and prime ministerial settings, as well as relative power positions and decades of international and domestic change, they confronted a shared dilemma of balancing moral appeals with practical politics. In seeking U.S. entry into World War I, Wilson (1917b) laid down the rhetorical gauntlet, setting the U.S. on a crusade to make the world 'safe for democracy.' Yet, these ambitions would be undermined as tensions at the Paris Peace talks in 1919 and 
congressional opposition impeded U.S. entry into the League of Nations, presaging the difficulties of the interwar era. Similarly, in 2007, Kevin Rudd would characterize climate change as the 'great moral challenge of our generation' as he urged an emissions trading scheme (ETS) which might provide an example to other states (Koutsoukis, 2007). Echoing Wilson, Rudd's pledge would be frustrated by parliamentary opposition and multilateral resistance at the Copenhagen summit in 2009, contributing to his decision to postpone the ETS and playing a part in his eventual political demise.

In highlighting these parallels, we advance three related arguments about the challenges to rhetorical leadership in modern democracies. Firstly, advancing on recent Historical Institutionalist scholarship (Thelen, 1999; Orren and Skowronek, 2004), we argue that tensions across the 'social distribution of knowledge' (Berger and Luckmann, 1966) can provide a source of policy instability, as emotionally-grounded speech conflicts with more cognitive - e.g., diplomatic, coalitional, or intellectual - rhetoric in ways that can cause credibility gaps, instability and crisis. Put differently, we echo Tulis’s (1987, pp. 9-13) critiques of 'institutional partisanship' with a similar focus on the costs of 'intellectual partisanship'. More precisely, we suggest that overconfidence in intellectual deliberation as an alternative to populist excess obscures the costs of intellectual insularity and benefits of ambiguity as a source of legitimacy and flexibility (Goodnight 1982; Best 2005; Bostdorff 2008). Secondly, we argue that such tensions pose a challenge for all democratic leaders, regardless of the system of government in which they operate. More specifically, we build on Tulis's analysis of the American 'rhetorical presidency' by suggesting that Westminster system prime ministers - though acting in completely different institutional contexts - face the same rhetorical challenges 
as presidents (Grube, 2010). Thirdly, we argue that a clearer understanding of the need for democratic leaders to engage in both 'inside' and 'outside' rhetoric can provide a more complete and nuanced picture of the rhetorical challenges that democracies place on their leaders. Outwardly powerful and committed leaders are shown to lack the power to manage major change unless they can successfully balance populist and intellectual rhetorics in a way that avoids credibility gaps from either vantage.

Having developed these theoretical arguments, we shift to an empirical focus on the limits to affective appeals by Wilson in the League debate and Rudd in advancing a climate change policy. In Wilson's case - advancing on Tulis's account - we situate his difficulties in the context of Progressive-era thought, as his rhetoric conflicted with senatorial and great power politics. In the Rudd case, we similarly situate his difficulties in tensions between the moral appeal of his arguments and parliamentary and multilateral (e.g., Copenhagen) tensions over climate change policies. In the conclusion, we stress the implications of tensions between outside and inside rhetoric for debates over global governance, comparative politics, and the interplay of populist and technocratic excesses.

\section{The Sociology of Political Rhetoric - Sentiment, Strategy, and Instability}

Over recent decades, debates over institutional change have been shaped by rationalist frameworks which presume that agents make efficient use of information (Muth, 1961; North, 1990). While not denying the utility of rationalist assumptions, we argue that they obscure the constitutive nature of rhetoric, the scope for deliberative instability and the endogenous sources of crises (Blyth, 2002; Widmaier, 2004). To redress these shortcomings, we argue that a broadly institutionalist stress on the 
impediments to deliberative efficiency is better suited to highlighting the different types of rhetoric that constitute popular beliefs, intellectual frameworks, and which can themselves cause policy instability. More formally, we argue for the importance of tensions across a 'social distribution of knowledge,' positing that rhetorical appeals which abstract away too far from either intellectual or popular settings can give rise to credibility gaps and eventual instability.

\section{From Institutionalist Approaches to the Social Distribution of Knowledge}

In recent decades, approaches to Comparative and International Political Development have been shaped by rationalist approaches which highlight the efficiency of varied agents - most importantly coalitional agents (Gourevitch, 1986) or norm entrepreneurs (Finnemore and Sikkink, 1998) in making use of information. Yet, even as such approaches provide useful insights, they underrate the scope for disruption, reducing instability and crises to deus ex machina-styled exogenous shocks. Partly to redress these oversights, recent years have seen the emergence of a broad Historical Institutionalist approach highlighting the Weberian-styled pathologies which generate instability (Thelen, 1999; Orren and Skowronek, 2004; Mahoney and Thelen, 2010). Characterizing such perspectives, Kathleen Thelen (1999) argues that they stress the ways in which the 'layering' of ideas and institutional orders can impede policy cohesion. Where ideas and institutions provide the underpinnings of policy orders, successive orders may interact in destabilizing fashions over time. To the extent that such institutional accumulation mounts over time, Thelen $(1999$, p. 382) argues that 'the various pieces do not necessarily fit together into a coherent, self-reinforcing, let alone functional, whole.' In 
this light, a key source of change comes from the interplay of dysfunctional institutional orders. Or, as Thelen (1999, p. 383) puts it, 'change comes from the interactions of different institutional orders within a society,' as they combine in ways that alternatingly give rise to instability or enable new possibilities.

With respect to specific concerns for policy rhetoric, this stress on the juxtaposition of institutional logics can be seen most clearly in studies of the American presidency. In particular, Jeffrey Tulis' seminal work on the rhetorical presidency has created an increasingly vast field of scholarship seeking to interrogate how and why the U.S. rhetorical presidency communicates (Medhurst, 1996; Friedman 2007; Garsten 2007; Tulis 2007; Stuckey, 2010; Friedman and Friedman 2012). Tulis' introduction of the rhetorical presidency into modern scholarship re-cast our understanding of the institutional shape of the U.S. presidency itself. Neustadt's (1960) 'power to persuade' was revealed as being underpinned by an institutionalized 'need to persuade' in order to successfully exercise democratic leadership. In the system of shared power enshrined in the U.S. constitution, the rhetorical presidency has provided the key avenue through which a president can go over the head of Congress and seek to connect directly with the American people.

More specifically, Tulis casts the U.S. constitutional order a 'layered text' in characterizing an incomplete transformation of norms governing presidential speech. First, describing a foundational 'Old Way,' Tulis (1987, p. 27) stresses the framers' desire that deliberation be exercised in the legislative setting, as they feared 'the danger that a powerful executive might pose... if power were derived from the role of popular leader.' In particular, they feared that such leadership might devolve into demagoguery, 
relying on appeals to emotion and popular passions. While Tulis (1987, p. 30) concedes that the framers lacked 'a straightforward answer' to the problem of demagoguery, he argues that they addressed it indirectly by assigning the key deliberative role to the legislature. To be sure, a cursory understanding of American politics suggests that this order has been since supplanted. In this light, Tulis secondly characterizes a second order or 'New Way' by citing the influence of the late nineteenth century doctrinal critique advanced by Woodrow Wilson, who argued in his Congressional Government that only the president stood capable of identifying a national interest. However, Tulis (1987, pp. 17-18) further notes that while Wilson's critique overlaid the founding vision, it did not displace it. In this light, the contemporary rhetorical presidency is 'buffeted by two constitutions,' leading presidents to speak in two voices as they play both a behind-thescenes role in intellectual and transactional debates and a public one in providing 'continuous presidential leadership of public opinion.'

Highlighting the implications of this layering, Tulis addresses key inefficiencies in U.S. policymaking. First, Tulis (1987, p. 46) argues that these contradictory rhetorical norms are a source of recurring credibility gaps that plague public discourse, as presidents suffer a role confusion in which their appeals to broad ideals 'fashioned for all' are undermined by the qualifications that shape in-government interactions and so are not 'available to all.' Put differently, they face pressures to speak out of 'both sides of their mouth' in ways that can spur the appearance of instability. Secondly, in the absence of opportunities for refined deliberation, Tulis (1987, pp. 178-179) suggests that presidents will increasingly seek to cast events as unprecedented crises to legitimate reform. Such appeals can in turn degrade the public's ability to engage in more gradual policy 
adjustment and prompt a broader 'decay of political discourse,' as deliberation is supplanted by 'competition to please or manipulate the public.' Tulis (1987, pp. 181) concludes that a paradoxical long term result of the routinization of crisis might be to 'make presidents less capable of leadership at any time,' as it has impeded the ability of agents 'to distinguish genuine from spurious crises,' leaving the rhetorical presidency to be 'the creator of crises, or pseudo-crises.' Friedman (2007, p. 205) stresses this aspect of Tulis's argument, warning that, as reliance on public rhetoric grows, leaders face pressures to make 'problems to be solved by some new law [appear to be]... urgent, and the proposed law must be made to seem a panacea, if the public is to be mobilized to back the new law. Consequently, the rhetoric of everyday politics is now characterized by alarm and exaggeration - that is, of untruth.' Or, as Tulis (1987, p. 179) puts it, 'The rhetorical presidency enhances the tendency to define issues in terms of the needs of persuasion rather than to develop a discourse suitable for the illumination and exploration of real issues'.

Yet, while there is much to commend in Tulis's analysis, we argue that it remains limited in three ways: First, we argue that it overrates the specificity of these dilemmas to American politics. To the extent that all political systems are shaped by a social distribution of knowledge or intellectual division of labor, tensions are likely to emerge between rhetoric meant for the public and more refined 'in-group' settings. Secondly, even as Tulis (1987, pp. 181) at times does seek a balanced tone in acknowledging the merit of public engagement - conceding that the rhetorical presidency can be 'both good and bad' - he ultimately views the social distribution of knowledge through an intellectually partisan lens. From this perspective, emotional appeals and public 
engagement disrupt intellect, and intellection refinement restores stability. The result is a sort of a 'rationalist lite' analysis, reflecting what Sharon Krause (2008, p. 2) terms a liberal tendency to 'betray a familiar fear about affect, which is that our passions will impugn the impartiality on which deliberation in matters of justice ought to rest'. In the process, Tulis underrates the ways in which what Jacqueline Best (2005) termed a ‘constructive ambiguity’ can help reconcile more discrete policy differences - a dynamic which has also been noted by presidential scholars, as when Bostdorff (2008, p. 109) posits the importance of a "strategic ambiguity" in the construction of the Truman Doctrine. Indeed, in his historical examples, Tulis (1987, pp. 147-173; 193-202) disproportionately highlights the costs of policy oversimplification - e.g., in the Kennedy-Johnson era 'War on Poverty' in subverting the deliberative process (Zarefsky 1986). In this context, however, he overlooks the equal potential for intellectual hubris e.g., on the part of 'best and brightest' economists of the Kennedy era. As Best (2005) has argued, miod-1960s intellectual claims that a "New Economics" would enable macroeconomic fine tuning were premised on an excess of technocratic abstraction that was every bit as prone to raise expectations as Johnson's public rhetoric regarding the potential to "cure" or "prevent" poverty. Third and finally, given bias toward intellectual efficiency, Tulis lacks a sense of the ways in which emotional and intellectual excesses interact over time. In this way, in a manner not dissimilar to psychological or institutional efforts regarding 'groupthink' (Janis, 1972) or policy pathologies (Barnett and Finnemore, 2004), Tulis identifies dysfunctional possibilities, but not the conditions under which they might intensify. 
The Social Distribution of Rhetoric: Ambiguity, Ambiguity Aversion and Credibility Gaps

To redress these oversights, we provide a social psychological context for the analysis of policy rhetoric, drawing on recent work highlighting the ways in which shared emotional and intellectual biases can impede deliberation (Crawford, 2000; Ross, 2006). We more formally situate Tulis's analysis in a sense of what Berger and Luckmann (1966) term the 'social distribution of knowledge' across the more ambiguous affective appeals that prefigure cognitive beliefs and interests. From this vantage point, 'primary' attitudes, or what 'everybody knows' about 'maxims, morals, proverbial nuggets of wisdom, values and beliefs' provide key bases for the more refined beliefs acquired in ‘secondary' settings (Berger and Luckmann 1966, p. 65). This distinction has been paralleled across an array of settings, to be sure - as in Goodnight's (1982) distinction between "technical" and "public" spheres of argument. Having drawn this distinction, we are then able to counter Tulis's intellectual partisanship, highlighting ways in which intellectual or populist certitude can exacerbate credibility gaps and instability.

In developing this framework, we make two key assumptions. First, we assume that inevitably-ambiguous emotional predispositions shape intellectual beliefs and policy preferences. As Andrew Ross (2006, pp. 199-200) argues, emotional predispositions are 'inspired and absorbed before being chosen' and 'tinge our intellectual beliefs' in ways that are 'experienced by decision-makers and publics alike.' Moreover, their ambiguous nature - as they are prone to varied interpretations - can provide a source of policy stability, sustaining consensus despite transactional and paradigmatic differences. Over time, such values can further acquire self-reinforcing momentums as they shape intellectual assumptions and coalitional perceptions. Where political rhetoric engages 
such concerns, it cannot be taken as a reflection, or mask obscuring, unproblematic underlying ideas or interests. Instead, it predisposes agents toward the more refined beliefs that sustain ideas or interests. As William Connolly (1987, p. 151) has argued, such rhetoric works 'to encourage or provoke participants to adopt specific orientations to political conduct', elaborating that '[t]he terms "encourage" and "provoke" identify precisely the loose and open quality of these relationships" in contrast to "a more formal account [that] would gloss over uncertainties and ambiguities'.

Secondly, to explain the conditions giving rise to such intellectual excesses, we employ a further assumption, holding that intellectual 'norm entrepreneurs' or members of professionally-defined epistemic communities may over time seek to limit the scope for ambiguity and emotional appeals in favor of paradigmatic refinement and 'flights into reason.' Where such agents engage in the precognitive repression - or exclusion from consciousness - of the emotional foundations of intellectual beliefs, we suggest that the resulting 'split' in the social distribution of knowledge can provide a key source of credibility gaps. Put differently, to the extent that emotional or qualitative appeals are ambiguous, shared tendencies to what Daniel Ellsberg (1961) termed 'ambiguity aversion' and a preference for formal or quantitative-styled evidence stands to engender inefficiency in the use of information and so 'irrational choices.' Indeed, as scholars like Daniel Kahneman (2011, pp. 8; 21) have argued, the exclusion of sentiment may be just as damaging as an excess of sentiment. Where 'systematic errors' reflect 'the machinery of cognition rather than... the corruption of thought by emotion,' intellectual biases may prevent agents from recognizing information at odds with paradigmatic expectations. Concern for such rigidity of course has an enduring pedigree, back to psychological 
discussions of defense mechanisms like the 'intellectualization', as agents seek to limit emotionally complicated aspects of any situations. In this light, where Tulis lauds intellectualization, this obscures the ways in which it reduces efficiency in the use of information, and the potential for the reconstitution of state and societal interests. From this vantage - as noted above - even as Tulis highlighted the limits to popular rhetoric in constructing the War on Poverty, he also obscured the parallel intellectual excesses of macroeconomic policymakers. The problem was less too much populism than intellectual excesses.

Combining these assumptions, we highlight the ways in which ambiguous moral appeals enable stability, while intellectualization and ambiguity aversion can prove destabilizing. More specifically, we suggest that this enables an improved appreciation of the conditions that see consensus yield to credibility gaps: On the one hand, speaking to the affective bases of popular consensus, we suggest that broad appeals on behalf of moral agendas can enable policy legitimacy and adaptability: In terms of legitimacy, emotional appeals can predispose the public toward specific paradigmatic beliefs. In terms of adaptability, ambiguity can enable policy adjustment to unforeseen developments, while reducing the likelihood that inexplicable events will be seen as a betrayal of ideals or a spur to transactional or paradigmatic conflict. On the other hand, in terms of intellectual excesses, we suggest that where political agents or intellectual advisers abstract too from affective contexts, this can impede popular legitimacy and engender overconfidence in policy control: In terms of adaptability, paradigmatic certainty will obscure the need for policy adjustment. In terms of legitimacy, the resulting divergence of public and policy views risk credibility gaps which can engender crisis and 
change. Taking these dynamics together, as Jacqueline Best $(2005$, p. 7$)$ frames it, 'too much ambiguity can be destabilizing, [but] too little can also be a problem' as a policy regime whose principles 'remain open to interpretation and negotiation can be stabilizing in a rapidly changing... environment,' while epistemic closure impedes adjustment and foreshadows declining legitimacy.

\section{Methodological Concerns}

In highlighting these tensions, we structure our approach to build on work examining aspects of the 'presidentialization' of prime ministers in parliamentary systems as it has addressed the interplay of leadership and rhetoric across different systems of government (Bowles, King and Ross, 2007; Theakston, 2011). This work suggests that there are inherent rhetorical challenges posed to democratic leadership that transcend the institutional make-up of a polity. In a Westminster system, the institutional motivation for engaging in public rhetorical appeals is not readily apparent. In a Westminster parliament, the prime minister by definition has the numbers to gain parliamentary approval for their program, and a prime minister who does not retain the confidence of the parliament must resign. While there are undeniably nuances that militate against quite such a straightforward characterization, the central concept is part of the basis of representative parliamentary democracy. In theory, a Westminster prime minister has only to sway the parliament in order to get their program through. This raises the question of not only why prime ministers spend so much time and energy giving speeches outside the parliament itself, but also broader concerns for the efficiency of parliamentary government, and whether policy pathologies that emerged from the 
rhetorical presidency may equally bedevil what Toye (2011) has termed the rhetorical prime ministership.

In highlighting these continuities, we note that - despite different systems of government, electoral systems, and political institutions - the central challenges of rhetorical leadership are strikingly similar: In both systems, leaders must construct a feasible narrative which embodies emotive and public elements and then utilize 'inside' or technical rhetoric to shape and guide policy outcomes that are not incongruent with their wider rhetorical positioning. In each case, the tensions between these imperatives can prove destabilizing, producing swings in public perceptions. To develop these insights, we trace in the following accounts the evolution of U.S. and Australian debates over national interests with respect to President Woodrow Wilson's effort to advance post-World War I collective security and Prime Minister Kevin Rudd's efforts to address climate change. Over each case, we juxtapose the evolving context of pronouncements geared to wider audiences - stressing the popular contexts of Wilson's and Rudd's own ideas - with the more refined statements directed toward epistemic communities and coalitional or diplomatic agents. In order to test the underlying utility of the rhetorical leadership concept beyond the specific U.S. context examined by Tulis, we adopt a 'least similar' case design to test whether the same institutional constraints that shaped Wilson's actions - as Tulis's examplar of a rhetorical president - could equally shape the actions of an Australian prime minister nearly a century later. Indeed, these cases comprise two policy conflicts that not only allow for a 'least similar' case design, but also allow for an analysis of how intellectual partisanship - rather than populist excesses - in policy debates can be said to be a long-established problem of rhetorical leadership, 
rather than merely a contemporary phenomenon. In the conclusion, we address theoretical and policy implications.

\section{Constructing Wilson's Credibility Gap: From Exhortation to Exhaustion}

Over the early twentieth century, the rise of Progressive ideas provided an ethical basis for an expansion of America's role as a great power and commercial actor. This could be seen at first more clearly in the economic realm, as Rooseveltian advocates of a 'New Nationalism' urged the management of economic power, while Wilsonian advocates of 'New Freedoms' favored the dismantling of market power to enable harmonious competition. Significantly, speaking to the deep structuring effects of ethical predispositions, this difference paralleled itself in the realm of foreign policy, where a Rooseveltian approach to managing the balance of power countered a Wilsonian stress on the harmony of interests among states that stressed the need for supportive institutions. Initially, the differences between these views mattered less than the deeper accord on an expanded scope for foreign and economic policy. However, this constructive ambiguity would prove increasingly difficult to reconcile with the partisan and great power differences underlying Wilson's vision of the League of Nations Treaty. While Wilson would seek to reconcile the demands of the 'inside' games of senatorial and global politics with the 'outside' game of public rhetoric, eventually the gap between these discourses became too great to bridge, and the defeat of the League Treaty would spur an isolationist backlash destined to last nearly two decades.

\section{Ethical Foundations: National and Individual}


At the turn of the twentieth century, U.S. foreign policy debates shifted to a more assertive stance, an approach in broad accord with the ethos underlying the Progressive movements. By the 1890s, the moment at which the U.S. could - as Washington had put it - 'defy material injury from external annoyance' had come, enabling U.S. policymakers to aspire to shape the evolution of global politics. Though varieties of Progressives differed over the precise nature of U.S. interests, support existed for an ambiguous blend of balance-of-power realism and crusading liberalism - often in support of the same policy actions. For example, U.S. entry into the Spanish-American War reflected both a realist-styled desire to exert a global influence and internationalist-styled calls for the liberation of Cuba. To be sure, through to the election of Woodrow Wilson to the presidency in 1912, foreign policy debates were secondary to economic matters. In one widely-noted comment, Wilson remarked to a colleague that 'It would be an irony of fate if my administration had to deal chiefly with foreign problems, for all my preparation has been in domestic matters' (Cooper 2009, p. 282).

However, to the extent that similar ethical predispositions shaped Progressive debates across the economic-foreign policy divide, this remark would prove something of an exaggeration. Indeed, Wilson himself had long woven his notions of social and legal order equally into discussions of domestic and international law. In a deep sense, his political worldview was shaped by Christian notions of Natural Law and as a force for ordering human interactions. As a scholar, he stressed the links between Christianity, the brotherhood of man, and the links between nations, arguing that 'regardless of race or religion... fundamental, vital principles of right' emanated from God to shape 'the universal conscience of mankind,' with nationhood depending on a state's recognition of 
these 'common principles of right' (Knock 1992, p. 8). Beyond Wilson, such views could be seen in millennial visions of the U.S. as a divinely favored nation, above the plane of balance-of-power styled politics or nationalist tensions, and so proving an enduring 'blind spot' in U.S. foreign policy (Hartz, 1955).

In this light, while the August 1914 outbreak of hostilities in Europe would see Wilson's focus shift to foreign policy, his instincts accord with his own brand of Progressivism, seeking at first to position the U.S. as a neutral arbiter that might advance a diplomatic solution. For example, in his January 1917 'Peace without Victory' address, Wilson (1917a) combined a traditional American antipathy toward balance of power competition with support for an interstate 'covenant' to shape the postwar peace.

Reframing the purposes of the conflict, Wilson argued that ' $[\mathrm{t}]$ here must be, not a balance of power, but a community of power... [and] an organized common peace.' Deploying Hamiltonian language to advance Jeffersonian principles, he argued that states should 'avoid entangling alliances which would draw them into competitions of power,' and instead unite 'in the common interest... under a common protection.' Taken as a whole, the speech foreshadowed key aspects of the Fourteen Points in its content and in its domestic response - marked by opposition from Isolationist Progressives like Idaho Republican Senator William Borah and his more realpolitik-visioned colleague Massachusetts Senator Henry Cabot Lodge (Cooper 2009, pp. 372-373).

Yet, in the immediate context, domestic and foreign reactions alike would be muted, as the January 1917 German announcement of unrestricted submarine warfare eventually brought the U.S. into the conflict. In his April 1917 war message to congress, however, Wilson would continue to inveigh against power politic, arguing that the aim of 
the U.S. would not simply be to reshape any balance of power, but rather to wage a war to make the world 'safe for democracy.' While much of the remainder of the year would be given over to domestic and international planning, Wilson and allies from academia and the media launched in September what would be termed the 'Inquiry,' cast by biographer John Milton Cooper as 'a freestanding organization outside the State Department that would become famous as a covey of experts who brought knowledge and brainpower to the gathering of information and analysis about matters involved in a peace settlement' (Cooper 2009, p. 419). The Inquiry's research would subsequently provide a key basis for the January 1918 'Fourteen Points' address. This was particularly true of the more specific points - e.g., regarding Poland, Russia and Alsace-Lorraine which would matter less over the long term than Wilson's (1918) concluding argument that a 'general association of nations must be formed under specific covenants for the purpose of affording mutual guarantees of political independence and territorial integrity to great and small states alike.'

To be sure, Wilson may have overrated the extent to which his principles were shared by the public. In November 1918, Wilson - just days before the armistice appealed nationally for the return of the Democratic congress, and suffered defeat, with Republicans gaining majorities in the House and Senate (Cooper 2009, pp. 445). Nevertheless, Wilson would over the next year exude a continuing faith in the scope for his own rhetorical appeals.

Credibility Gaps: International, Congressional and Public Rhetoric 
To the extent that the essence of a credibility gap lies in the tensions between rhetoric directed toward 'in group' and 'out-group' agents, Wilson would effectively present to the public a quite different view of the League than that which was held in Europe or the Senate. The first signs of tension emerged on the international front, as Wilson's call for a 'peace without victory' would collide with the actual treatment of the Germans by the allies, who would require that Wilson accept this adverse treatment as the cost of support for the League. Indeed, after the May 1919 unveiling of terms to the Germans, Wilson himself remarked to his Secretary of War Newton Baker 'If I were a German I think I should never sign [the treaty]' (Cooper 2009, p. 495). When the German delegation was presented with the terms, and given no option but to sign, the German foreign minister protested that 'We are required to admit that we alone are war-guilty; such an admission on my lips would be a lie' (Cooper 2009, p. 495). In this context, a credibility gap manifested itself almost immediately in Paris, where Wilson's own aides voiced their disillusion to one another. In a moment of historical irony, Herbert Hoover and John Maynard Keynes encountered one another on the morning of May 7, each filled with concern over the terms of the treaty, and a number of Wilson's staffers would resign in protest. Nevertheless, Wilson would continue to suppress his own criticisms of the Treaty, pointing to 'the other leaders' insistence on secrecy' (Cooper 2009, p. 496). In a deeper sense, Wilson's silence reflected the contradiction between a transactional settlement and an aspirational League. While recognizing the unfair nature of the legal settlement, Wilson held out for the possibility that the damage might be undone by the League. 
This faith in the League was not shared in the Senate, where the League was seen as a potential infringement on U.S. sovereignty. Having invited no prominent Republicans to Paris, Wilson faced substantial Republican criticism over Article 10 of the League Covenant, which obligated members to 'undertake to respect and preserve as against external aggression the territorial integrity and existing political independence of all Members of the League.' In confronting this challenge Wilson had essentially two directions in which he could move - toward appealing directly to the Senate and making compromises on the League Treaty - at the risk of alienating the wider public - or toward insisting on unqualified attachment to the Treaty ideals - and so by fall 1919 would increasingly resort to demagoguery in characterizing the alternative views of his opponents as lacking in principle (Hogan 2006). At his first address to the Senate upon returning from Paris in July 1919, Wilson sought to reconcile the two imperatives, warning that rejecting the Treaty would 'break the heart of the world' while exercising restraint in engaging opponents. Yet, in terms of senatorial reaction, the speech would fail, as Republicans denounced 'Soap bubbles and a soufflé of rhetorical phrases' (Cooper 2009, pp. 507-508). Nevertheless, Wilson would over the summer of 1919 continue to engage the Senators. Ironically, in these settings, Wilson was forced to concede to his Republican adversaries that 'the heart of the world' would not be broken, at least not to the extent that many in Europe opposed the Treaty itself. Indeed, his private language in dealings with Republicans often stressed concerns for realpolitik and difficulties with European allies. For example, Wilson suggested to the members of the foreign relations committee at a private meeting in August 1919 that U.S. participation was essential to overcoming European skepticism. 
However, such efforts ultimately failed, and Wilson subsequently embarked on a national tour, going 'over the heads' of congress to the public (Cooper 2009, pp. 518). In his ensuing public statements, Wilson argued that the world was desperate for the League and U.S. participation, even associating his Republican rivals with a spirit of 'Bolshevistic' opportunism. In late September, Wilson collapsed, and returned to Washington - where the Treaty would ultimately be rejected, reflecting in no small part the 'Old Way' insulation of the Senators from the rhetorical pressures. In this immediate context, as Tulis (1987, p. 21) suggests, Wilson was confounded 'by competing imperatives of the two constitutions.' Yet, we stress that Wilson's errors cannot be reduced to affective excesses, as affective influences on the part of his opponents - in their attachment to an ostensibly unambiguous realist verities - obscured the ways in which a desire to punish Germany would itself undermine European recovery - as famously argued by Keynes (1920): Secondly, to the extent that appeals during the Progressive era had led Americans to begin moving toward a broader definition of the national interest, Wilson's dilemma was itself only possible because of prior affective shifts. Indeed, Wilson's rhetoric eventually succeeded in advancing these impulses in American debates, and he himself would be reconstructed as a martyred visionary, and the post-World War II order would be shaped by a more balanced, if ambiguous “embedded liberal” variety of multilateralism (Ruggie 1982).

\section{Constructing Rudd's Credibility Gap: From Moral Challenge to Overthrow}

In a way that paralleled Wilson, Kevin Rudd's approach to politics was animated by a broad sense of purpose, as he affirmed at the 'Australia 2020' summit in Canberra in 
2008. 'I don't want to explain to my kids, and perhaps their kids, too, that we failed to act; that we avoided the tough decisions; that we failed to prepare Australia for its future challenges' (Stuart 2010, p. 1). Speaking specifically to environmental concerns, Rudd had campaigned in 2007 on a view of climate change as the 'great moral challenge of our generation' (Koutsoukis, 2007). Yet, over his term in office, the distance between Rudd's rhetoric and what scholars (Buttel, 2000; Bailey and Wilson, 2009; Curran, 2011) have cast as a more prosaic 'ecological modernization' (EM) approach to climate change would prove a source of a mounting credibility gap. Paralleling Wilson, Rudd would succeed in raising domestic expectations, only to encounter parliamentary and global opposition to his plan. When Rudd abandoned the issue in early 2010, the result would be a public backlash that undermined support within his own party and led to his ultimate overthrow. However, as with Wilson, Rudd's rhetoric had a 'life of its own,' presaging the Gillard government's subsequent enactment of climate change legislation.

\section{Ethical Foundations: National and Individual}

Over the late 2000s, Rudd played a similar role to that of Wilson in advancing Australian debate over climate change. Each confronted similar tensions, as common attempts at advancing narratives of moral challenge conflicted with behind-the-scenes trade-offs. In this way, Rudd cast climate change as a 'moral challenge' in rhetorical terms while adhering to a more technocratic ecological modernization approach in practice. While the former elevates moral concerns over utilitarian-styled cost-benefit analyses, the latter seeks to manage a utilitarian environmental-economic trade-off while sustaining prevailing social and institutional contexts (Curran 2011, p. 1007). Initially, 
however, the Liberal-National Coalition under John Howard (1996-2007) adopted neither a moral nor EM approach. Howard pursued instead what has been termed a policy of 'fossil fuel pragmatism' that stressed the need to limit the relative gains that would be incurred by Australia's unilateral acceptance of environmental obligations. This would be encapsulated in a 'No Regrets' policy, which held that Australia would accept no obligations that might impose relative costs on its economy - and so the government in particular refrained from ratifying the Kyoto Protocol (Curran, 2011). However, this reluctance would in the mid-decade be undercut by an Australian drought that was widely seen as a consequence of global warming, and by the pressures of the approach of the 2007 election, which together prompted the Howard government to move reluctantly to accept the reality of human-driven climate change (Christoff, 2005).

Nevertheless, from 2006 into the November 2007 campaign, the Howard government would find itself 'behind the curve' of pressure emanating from the Labor Party. In particular, Labor Party Leader Kevin Rudd had assumed an increasing media profile, staking out the position of public intellectual in a way that saw him 'go over' parliamentary debates in efforts to reshape public sentiment. In the environmental context, this would be most clear in an essay published in The Monthly, in which Rudd (2006) addressed not only the issue of climate change, but also spoke to broader differences with Howard over the scope for religion and values in public life. Loosely paralleling Wilson, Rudd countered views of religion as solely pertaining to personal choice and morality. Instead, he argued for a broadened scope for religious values, meant 'not to be socially agreeable,' but rather to 'speak robustly to the state on behalf of those who cannot speak effectively for themselves.' Addressing the implications for climate 
change, Rudd argued that 'the church's increasing engagement on the environment - and specifically on global climate change' reflected ethical imperatives, elaborating that 'the planet cannot speak for itself. Nor can the working peoples of the developing world... although they are likely to be the first victims of... climate change.' In this light, he argued that '[i]t is the fundamental ethical challenge of our age to protect the planet - in the language of the Bible, to be proper stewards of creation.' Rudd (2006) concluded by bringing on a critique of the Howard government that 'It is ethically indefensible for the current government to have spent the last decade not only refusing to ratify the Kyoto Protocol, but also actively working with the government of the U.S. to marginalise it.' Over the campaign, Rudd's advanced position would relegate Howard to the persistent status of playing 'catch-up.' Most enduringly, as noted above, at a March 2007 Labor Party Climate Change Summit, Rudd proclaimed climate change, 'the great moral challenge of our generation,' raising expectations of fast action. More specifically, in structuring the campaign itself, the Labor Party cast climate change as one of 'three target areas,' with industrial relations and education (Van Onselen and Senior 2008, p. 24). This pressure would push Howard by June 2007 to embrace climate change and promise 'a world class emissions trading system more comprehensive, more rigorously grounded in economics, and with better governance than anything in Europe' (Megalogenis 2012, p. 383) In an address to the Melbourne Press Club a month later, Howard said: 'it will provide a model for other nations to follow' (Dreyfuss, 2007). Ultimately, Howard was incapable of convincing the public of his credibility on the issue, and - in a result that is best seen as overdetermined, coming at the end of four terms in office - would be turned 
out by voters. Ironically, however, Rudd's aggressive campaign would have implications for his own subsequent credibility, having raised expectations to a remarkable degree.

\section{Credibility Gaps: International, Parliamentary and Public Rhetoric}

In the campaign, Rudd had stressed the moral basis of Australian interests with respect to climate change. To be sure, his first official move in office would be to ratify the Kyoto Protocol. However, in office, he would be forced to make legislative compromises, which would undercut his authority as a moral figure above politics. This would be particularly clear as he made early strategic decisions to adopt a more moderate plan, to appeal to the Liberals, despite the risk of alienating the Australian Greens. Indeed, the trajectory of policy debate over the Rudd term would be set by this decision, as the Global Financial Crisis put pressure on business, which in turn put pressure on Rudd, to limit the costs of any emissions reductions efforts.

The formal signification of this pivot would come in late 2008, as Rudd climate change advisor Ross Garnaut published a white paper which itself represented a compromise proposal, and which the government further weakened. For example, Garnaut urged that the government seek to reduce the output of greenhouse gasses by between 5-to-15 percent by 2020 , in relation to 2000 levels. However, while the Rudd government accepted this recommendation, it rejected Garnaut's associated argument that it should consider a 25 percent cut if the upcoming Copenhagen summit produce a global accord on these levels. Reflecting their attention to the 'bottom line' in the context of the accelerating GFC, they also rejected Garnaut's urging that industry compensation be limited, opting to distribute 25 percent of proposed permits to emitting companies facing 
international competition from rivals whose governments had not yet imposed such constraints (Taylor and Uren 2010, pp. 177-178; Curran 2011, pp. 1010-1011). In this technocratic manner, Garnaut and Rudd each remained within the EM framework.

However, this decision would set in play a dynamic that would only exacerbate the gap between Rudd's 'outside' rhetoric and 'inside' policymaking, requiring that Labor increasingly appease the Liberals and their business constituents. Given business pressures arising from the GFC - and the alienation of those who had hoped for an accord with the Greens - Climate Change Minister Penny Wing suggested in May 2009 that Labor risked an 'outcome where loss of support from the left and the right, for totally different reasons, meant you ended up with nothing. This would lead her to engage in behind-the-scenes talks (on the right) with the Business Council of Australia and the Australian Industry Group, and (on the left) the World Wildlife Fund and Australian Conservation Foundation. The result would be a series of shared compromises, including a year's delay in implementing the scheme, a promise to consider a 25 percent cut in Australia's emissions given a possible Copenhagen deal, and increased compensation for key industries (Taylor and Uren 2010, p. 181).

Yet, over the next six months, Labor would face a similar dilemma to that of Wilson: Just as Wilson had dealt with Republican 'irreconcilables,' Rudd had to deal with a revived skepticism toward climate change emanating from within the Liberal Party. To be sure, Howard had supported a strengthened policy in the campaign, and his environmental minister Malcolm Turnbull would go on to continue in this vein as the Liberals moved into opposition. Indeed, in May 2009, Turnbull even engineered coalition support for Rudd's planned position at the forthcoming Copenhagen summit, endorsing a 
5 percent unconditional emissions target and setting conditions for agreements of up to 25 percent. Yet, into late 2009, the Coalition would increasingly question both the science behind climate change and - reviving the 'No Regrets' stance - the wisdom of staking out a position prior to Copenhagen, with Liberal Tony Abbott arguing explicitly that the 'politics have changed' and that electoral imperatives justified efforts to draw sharper distinctions with Labor on climate change (Taylor and Uren 2010, p. 189). The key pivot came in December 2009, when Turnbull - having been weakened by a bizarre scandal over a forged e-mail alleging corruption on the part of Rudd - was deposed in favor of Abbott. On his first day as leader, Abbott submitted a secret ballot pulling back Liberal support for an ETS - overwhelmingly approved on a 54-29 vote - and then went on to deride it as a 'great big new tax on everything' (Taylor and Uren 2010, p. 196).

Having come to face a mounting domestic gap between promises and transactional possibilities, Rudd - weakened by the divisions in parliament - would in turn face similar tensions abroad, as the Copenhagen summit commenced a month after Abbott's rise to lead the opposition. In the approach to Copenhagen, rapidly developing nations - most importantly China, India, Brazil and South Africa - would increasingly argue that the summit was moving to unfairly restrict their growth - in ways that had not previously constrained now-developed states (Alter 2010, p. 359). Manifesting this skepticism, the Chinese government in particular often sent low-ranked officials to key meetings, which would then often be slowed when the officials would not only leave to seek advice, but also often return with instructions to further dilute any potential agreement (Taylor and Uren 2010, p. 200). With Rudd on the sidelines, U.S. President Barack Obama and Secretary of State Hillary Clinton arguably 'crashed' a meeting of the 
Chinese, Indian, Brazilian and South African heads of state. However, even after these efforts, they would be unsuccessful in obtaining concrete commitments from China only tentative support for the voluntary listing of emission targets and results on an international registry (Alter 2010, p. 360-361). In Australia, Abbott would treat the collapse as a 'vindication' (Taylor and Uren 2010, p. 202).

Rudd followed up on difficulties at the 2009 Copenhagen conference - and two unsuccessful attempts to pass the bill - by opting in April 2010 to defer a vote on an emissions trading scheme to 2013. To the extent that he might have called a 'double dissolution' election and sought the support of a new parliament, this further damaged his credibility with supporters of climate change. In this context, as his poll ratings began to fall - from admittedly impressive high numbers - his opponents in the party itself would turn on him, and by late July, he would be deposed by his own caucus (Cassidy 2010, pp. 49-50). In a way that mirrored Wilson, the very 'outside' skills that made Rudd an effective 'rhetorical prime minister' worked against him when he had to compromise in playing the 'inside game' of politics. However, as with Wilson, Rudd's rhetoric would retain a life of its own, and so when his successor Julia Gillard assembled a minority government in September 2010, her need for support from the Greens led her to reverse her own campaign pledge to oppose a carbon tax, enabling the eventual passage of a carbon tax and ETS scheme.

\section{Conclusions}

This analysis has both theoretical and policy implications: First, in theoretical terms, to the extent that it rests less on unique features of the U.S. order than pervasive 
tensions arising from the social distribution of knowledge (Berger and Luckmann 1966) or between the public and technical spheres of rhetoric (Goodnight 1982) it has relevance across international and comparative contexts. Indeed, given that Wilson was Tulis' paradigmatic example of a president who reached out to the public over other institutions of government, our 'least similar' case highlights the ways in which rhetorical norms transcend formal institutional structures, shaping the practices of presidents and prime ministers alike. To be sure, this analysis should not be mistaken for a fatalistic one. Indeed, it instead can also be seen as highlighting the ways in which rhetorical appeals that face early setbacks can also generate later payoffs - as the rhetoric of Rudd and Wilson would shape the efforts of their successors.

Secondly, this analysis suggests the need for a wider perspective on the sources of intellectual or populist excesses, and the overlooked ways intellectual partisanship can impede policy efficiency. To be sure, even as scholars have often noted the existence of tensions between rhetorical appeals and technocratic practicalities, these tensions are often seen from an intellectually partisan vantage. Yet, as Goodnight (1982, 223-224) has argued, to the extent that 'the public sphere is being steadily eroded by... technical groundings of argument', the public stock of shared knowledge 'may be disappearing'. Ironically, in recent scholarship such trends to a devaluing of the public sphere are often heralded. Such intellectual partisanship can be found in not only Tulis's arguments, but also International Relations work on the role of 'norm entrepreneurs', which casts leaders as - at best - intervening agents who translate intellectual frameworks into policy reality (Finnemore and Sikkink 1998). In contrast, our analysis suggests that norm entrepreneurs must themselves adjust to moral sentiments, and that excessive intellectual autonomy - or 
Krause's (2008, p. 2) ironic 'fear about affect' - can exacerbate instability. In this way, the presidential or prime ministerial context of debate matters less than shifts in the social distribution of knowledge that foreshadow tendencies to populist excess or intellectual partisanship. 


\section{Sources}

Alter, J. (2010) The Promise: President Obama, Year One. New York: Simon and Schuster

Bailey I., and Wilson, G. (2009) 'Theorising Transitional Pathways in Response to Climate Change: Technocentrism, Ecocentrism, and the Carbon Economy', Environment and Planning A 41, 2324-2341

Barnett, M., and Finnemore, M. (2004) Rules for the World. Ithaca: Cornell University Press.

Berger, P., and Luckmann T. (1966) The Social Construction of Reality. New York: Anchor Books.

Best, J. (2005) The Limits of Transparency: Ambiguity and the History of International Finance. Ithaca: Cornell University Press.

Blyth, M. (2002) Great Transformations: Economic Ideas and Institutional Change in the Twentieth Century Cambridge: Cambridge University Press.

Bortsdorff, D. (2008) Proclaiming the Truman Doctrine: The Cold War Call to Arms College Station: Texas A\&M Press

Bowles, N., King, D. and Ross, F. (2007) 'Political Centralization and Policy Constraint in British Executive Leadership: Lessons from American Presidential studies in the Era of Sofa Politics', British Politics, 2 (3), 372-394

Buttel, F.H. (2000) 'Ecological Modernization as Social Theory,' Geoforum 31, 57-65;

Cassidy, B. (2010) The Party Thieves: The Real Story of the 2010 Election, Melbourne: Melbourne University Press.

Christoff, P. (2005) 'Policy Autism or Double-Edged Dismissiveness? Australia's Climate Policy under the Howard Government', Global Change, Peace and Security 17, 29-44

Connolly, W. (1987) 'Appearance and Reality in Politics' in Interpreting Politics, ed. by Michael T. Gibbons, pp. 148-174, New York University Press.

Cooper, J.M. (2009) Woodrow Wilson: A Biography. New York: Vintage

Crawford, N. (2000) 'The Passion of World Politics: Propositions on Emotion and Emotional Relationships,' International Security 24 (4), 116-156.

Curran, G. (2011) 'Modernising Climate Change in Australia: Climate Narrative and the 
Undoing of a Prime Minister,' Environment and Planning C: Government and Policy $29,1004-1017$

Dreyfus, M. (2011) 'Liberals' Carbon Confusion,' The Age (August 4) Available from: http://www.theage.com.au/opinion/politics/blogs/the-dreyfus-files/liberalscarbon-confusion-20110803-1ibbs.html

Ellsberg, D. (1961) 'Risk, Ambiguity and the Savage Axioms,' Quarterly Journal of Economics 75, 643-669

Finnemore, M., and Sikkink, K. (1998) 'International Norm Dynamics and Political Change,' International Organization 52, 887-917.

Friedman, J. (2007) 'A "Weapon in the Hands of the People": The Rhetorical Presidency in Historical and Conceptual Context', Critical Review 19 (2-3): 197-240

Friedman, J., and Friedman, S. (2012) Rethinking the Rhetorical Presidency. Routledge

Garsten, B. (2007) 'The Idea of an Un-Rhetorical Presidency', Critical Review 19 (2-3): 325-334

Goodnight, G. T. (1982). 'The Personal, Technical, and Public Spheres of Argument', Journal of the American Forensics Association. 18: 214-227.

Gourevitch, Peter. 1986. Politics in Hard Times: Comparative Responses to International Economic Crises. Ithaca, NY: Cornell University Press.

Grube, D. (2010) 'The Rhetorical Framing of Policy Intervention', Australian Journal of Political Science, 45 (4), 559-578.

Hartz, L. (1955) The Liberal Tradition in America. New York: Harcourt, Brace and Co.

Hogan, J.M. (2006) Woodrow Wilson's Western Tour: Rhetoric, Public Opinion, and the League of Nations College Station: Texas A\&M University Press

Janis, I. (1972) Victims of Groupthink. Boston: Houghton-Mifflin

Kahneman, D. (2011) Thinking Fast and Slow. New York: Penguin.

Keynes, J.M. (1920) The Economic Consequences of the Peace. New York: Harcourt Brace.

Knock, T.J. (1992) To End all Wars: Woodrow Wilson and the Quest for a New World Order. Princeton: Princeton University Press.

Koutsoukis, J. (2007) 'Rudd Plans China talks on Climate,' The Age (April 1) Available from: http:/www.theage.com.au/news/national/rudd-plans-china-talks-onclimate/2007/03/31/1174761817910.html 
Krause, S. (2008) Civil Passions: Moral Sentiment and Democratic Deliberation. Princeton: Princeton University Press

Mahoney, J. and Thelen, K. (eds.) (2010) Explaining Institutional Change: Ambiguity, Agency, and Power. Cambridge: Cambridge University Press.

Medhurst, M. J. (ed.) (1996) Beyond the Rhetorical Presidency. College Station: Texas A\&M University Press.

Megalogenis, G. (2012) The Australian Moment. Camberwell, Victoria: Viking.

Muth, J. (1961) 'Rational Expectations and the Theory of Price Movements,' Econometrica 29, 315-360

Neustadt, R. (1960) Presidential Power. New York: Macmillan Publishing Company:

North, D. (1990) 'A Transactions Cost Theory of Politics'. Journal of Theoretical Politics, 2 (4), 355-367

Orren, K., and Skowronek, S. (2004) The Search for American Political Development Cambridge: Cambridge University Press.

Onselen, P.V., and Senior, P. (2008) Howard's End: The Unraveling of a Government. Melbourne: Melbourne University Press.

Ross, A. (2006) 'Coming in from the Cold: Constructivism and Emotions' European Journal of International Relations 12 (2), 197-222

Rudd, K. (2006) 'Faith in Politics', The Monthly (October) Available from: http://www.themonthly.com.au/faith-politics-kevin-rudd-300

Ruggie, J.G. (1982) 'International Regimes, Transactions, and Change: Embedded Liberalism in the Postwar Economic Order', International Organization 36(2):379-415.

Stuart, N. (2010) Rudd's Way, November 2007-June 2010. Melbourne: Scribe.

Stuckey, M.E. (2003) "'The Domain of Public Conscience": Woodrow Wilson and the Establishment of a Transcendent Political Order', Rhetoric and Public Affairs, 6 (1): $1-23$

Stuckey, M. E. (2010) 'Rethinking the Rhetorical Presidency and Presidential Rhetoric', The Review of Communication, 10 (1), 38-52.

Taylor, L. and Uren D. (2010) Shitstorm. Melbourne: Melbourne University Press 
Theakston, K. (2011) 'Gordon Brown as Prime Minister: Political Skills and Leadership Style’, British Politics, 6 (1), 78-100

Thelen, K. (1999) 'Historical Institutionalism in Comparative Politics', Annual Review of Political Science 2, 369-404.

Toye, R. (2011) 'The Rhetorical Premiership: A New Perspective on Prime Ministerial Power since 1945', Parliamentary History 30 (2), 175-192.

Tulis, J. K. (1987) The Rhetorical Presidency. Princeton: Princeton University Press.

Tulis, J. K. (2007) 'The Rhetorical Presidency in Retrospect', Critical Review 19 (2-3), 481-500.

Widmaier, W. (2004) '"The Social Construction of the 'Impossible Trinity": The Intersubjective Bases of Monetary Cooperation', International Studies Quarterly $48,433-453$.

Wilson, W. (1917a) 'Address to the Senate on Peace Without Victory', (January 22, 1917) Available from: http://wwl2.dataformat.com/Document.aspx?doc $=30688$

Wilson, W. (1917b) 'President Woodrow Wilson's War Message', (April 2) Available from: www.lib.byu.edu/ rdh/wwi/1917/wilswarm.html

Wilson, W. (1918) 'President Wilson's Fourteen Points', Address to a Joint Session of Congress (January 8,) Available from: http://wwi.lib.byu.edu/index.php/President Wilson's Fourteen Points

Zarefsky, D. (1986) President Johnson's War on Poverty: Rhetoric and History University of Alabama Press. 